\title{
URGENSI KURIKULUM DALAM PRESPEKTIF PENDIDIKAN ISLAM
}

\author{
Oleh Mariatul Hikmah \\ STAI Nurul Falah Air Molek \\ Email: mariatulhikmah77@gmail.com
}

\begin{abstract}
Sebagaimana kita ketahui bahwasanya pembaharuan terus saja terjadi dalam kurikulum, karena kemajuan kurikulum terus saja terjadi mengikuti kemajuan zaman. Kurikulum memiliki sifat dinamis selalu mengikuti keberadaan masa sesuai dengan perkembangan teknologi. Frankin Bobbit mengatakan bahwa kurikulum yang baik akan mampu mendiagnosa kesulitan belajar siswa. Kajian pada karya ilmiah ini terkait dengan keberadaan kurikulum masa orde baru di Madrasah Aliyah. Adapun factor yang sangat mempengaruhi pembaharuan kurikulum di masa orde baru terkait dengan komponen yang ada dalam pendidikan yang meliputi kurikulum itu sendiri, komponen, dan tujuan serta metode yang ada dalam kurikulum. Penelitian bersifat kualitatif deskriptif dengan teknik pengumpulan data wawancara, observasi, dan dokumentasi. Informan yang digunakan tidak menentu (snowball). Hasil Penelitian Di masa orde baru kurikulum yang ada di Madrasah Aliyah sudah bersifat nasional yakni sejak tahun 1973. Dominasi pelajaran umum di Madrasah Aliyah sudah mulai kelihatan, mata pelajaran agamanya mulai menyempit yang dibagi dengan mata pelajaran umum. Kurikulum di masa ini mulai menampakkan keseragamannya sehingga bisa disebut desentralisasi. Pembaharuan kurikulum terus terjadi yang meliputi kurikulum 1975, kurikulum 1984, UUSPN N0 2 tahun 1989, yang intinya menyatakan bahwa isi kurikulum di MA disamakan dengan kurikulum di SMU da nada beberapa penambahan mata pelajaran agama untuk mempertahankan isi dari sebuah kurikulum.
\end{abstract}

Kata Kunci: Kurikulum, Orde Baru, Madrasah Aliyah 


\title{
URGENSI KURIKULUM DALAM PRESPEKTIF PENDIDIKAN ISLAM
}

\author{
Oleh Mariatul Hikmah \\ STAI Nurul Falah Air Molek \\ Email: mariatulhikmah77@gmail.com
}

\section{Pendahuluan}

Perjalanan Kurikulum Ma Masa Orde Baru Kebijakan yang mencakup pembaharuan kurikulum MA yang ada di Indonesia terus saja berputar terus mengiringi fase pendidikan yang ada. Pembaharuan pada masa orde bar uterus saja berjalan dan terus mengalami pergeseran baik yang terkait dengan komponen, tujuan, isi, metode, maupun media yang ada. Munculnya kurikulum secara nasional terjadi setelah tahun 1973, yang mana isi dari kurikulum di masa itu sudah berjalan secara seragam, sehingga implikasi yang terlihat dengan munculnya SKB 3 menteri yang terkait dengan mutu pendidikan pada madrasah.

Lantas bagaimana perjalanan kurikulum sesuai dengan kebijakan yang ada ? Kebijakan yang telah dibuat, yang mana keputusan ini dibuat berdasarkan pada keputusan yang ada yakni keputusan menteri agama No 75 tanggal 29 September 1976, yang telah diberlakukan secara intensif mulai dari tahun 1978. Bagaimana dengan kelanjutan kurikulum 1984 yang disempurnakan pada kurikulum tahun 1987? Penyempurnaan kurikulum yang ada sejalan dengan perubahan kurikulum sekolah di lingkungan departemen pendidikan dan kebudayaan. ${ }^{1}$

\footnotetext{
${ }^{1}$ Peran Madrasah untuk mencerdaskan kehidupan bangsa. Yang dapat dilihat dari UU pendidikan pada tahun 1950. Dengan bergesernya peran pembaharuan kurikulum dari tahun 1950 ke tahun 2019, maka tidak akan dapat teralpakan bagi peran Madrasah yang ikut dalam $m$. 
Kurikulum MA terus mengalami pembaharuan dan dengan berbagai kebijakan yang berperan dalam melaksanakan produk politik,yang terus mempunyai hubungan dengan kebijakan yang telah dikeluarkan oleh pemerintah yang terkait dengan kebijakan kurikulum yang ada.

\section{Metode}

Penelitian ini bersifat kualitatif dengan menggunakan teknik deskriptif. Adapun lokasi penelitian di Madrasah Aliyah (MA). Dalam pengumpulan data, ada 2 data yang digunakan yaitu: data primer dan data sekunder. Data primer, data yang diambil dengan cara terjen langsung dan melibatkan narasumber. Dengan teknik observasi (pengamatan) dan wawancara. Wawancara dilakukan secara mendalam, dengan informan snowbol. Dan terakhir menggunakan data sekunder didapatkan dari dokumen yang berupa foto, dokumendokumen (data-data).

\section{Pembahasan}

\section{Pendidikan}

Berbicara tentang pendidikan, maka tidak bisa terlepas dari program yang ada di dalam pendidikan. Program disebut juga kurikulum yang merupakan sebuah rencana tertulis mesti dikuasai peserta didik dalam proses pengajaran, yang tidak bias dipisahkan dari unsur komponen pendidikan.

Manusia yang potensial memerlukan perolehan pendidikan yang baik. Tanpa pendidikan, manusia tidak akan mampu untuk dappat mengeksplorasikan diri. Banyak sekali teori potensi manusia yang tidak hanya dipengaruhi oleh factor genetic, factor ligkungan juga sangat mempengaruhi. Salah satunya adalah teori tabularasa yang dipelopori oleh John Lucke. Anak diibaratkan seperti kertas putih dan potensi yang dimiliki oleh anak dipegaruhi oleh factor pengalaman yang didapat dari dunia luar. Teori ini tidak seratus persen benar karna potensi yang ada pada anak didik juga dipengaruhi oleh factor genetic sesuai dengan pendapat wilyam Stern. Ini sangat sesuai dengan analisis penulis bahwasanya untuk mengembangkan potensi yang ada pada anak didik 
sangat dipengaruhi oleh dua factor yakni factor genetic dan lingkungan. Intinya bahwa perkembangan dari potensi anak didik sangat mempengaruhi terhadap program yang dibuat dalam sebuah rancangan kurikulum.

\section{Kurikulum}

Pandangan lain bahwa pengertian kurikulum merentang dari yang sangat sederhana, yakni kurikulum merupakan kumpulan sejumlah mata pelajaran, sampai kurikulum pengembangan kecakapan hidup (life skill), dikemukakan oleh scubert tahun 1986, yang menyatakan bahwa kurikulum memuat: Sejumlah mata pelajaran, program kegiatan pembelajaran yang direncanakan, hasil belajar yang diharapkan, reproduksi kebudayaan, dan pengembangan kecakapan hidup. Kurikulum sebagai kumpulan sejumlah mata pelajaran merupakan pengertian kurikulum yang menghubungkan dengan daftar mata pelajaran yang harus diajarkan. Kurikulum sebagai program kegiatan pembelajaran yang direncanakan, artinya perencanaan ruang lingkup urutan, keseimbangan mata pelajaran, tekhnik mengajar, dan hal-hal lainnya yang dapat direncanakan sebelumnya dalam pembelajaran.

Kurikulum sebagai hasil belajar bertujuan memberikan focus hasil belajar yang dapat dipertanggungjawabkan secara terbuka. Kurikulum sebagai reproduksi kebudayaan dimaksudkan untuk mencapai tujuan pendidikan nasional, ketika pemerintah menuntut para pendidik untuk membangun generasi yang mempunyai peradaban dan bermartabat yang tinggi, bertahan, berdaya saing serta mampu menyesuaikan diri dengan perkembangan zaman. Kurikulum sebagai pengembang kecakapan hidup, bertujuan mengembangkan kecakapan akademik, kecakapan pribadi, kecakapan sosial, dan kecakapan vokansional peserta didik. $^{2}$

Sebenarnya pola piker perkembangan kurikulum sudah dikatakan modern di tahun 1986, sudah meranah pada banyak aspek. Di Indonesia kurikulum yang sudah merambah banyak aspek ini terkait dengan masa orde baru, ada pencerahan pengertian kurikulum di sana. Terlebih kurikulum MA, yang lebih matang bila dibanding dengan keberadaan kurikulum MA di masa orde lama.

\footnotetext{
${ }^{2}$ Herry Widyastono, 'Pengembangan Kurikulum Sekolah Bertaraf Internasional', Jurnal Pendidikan dan Kebudayaan, vol. 16, no. 3 (2010), p. 5.
}

32 Jurnal Madania: Volume 9 : 1, 2019 (e-ISSN 2620-8210 | p-ISSN 2088-3226) 
Pendapat lain yang mendudukung pengertian kurikulum dalam pandangan modern menyatakan bahwa yang dinamakan kurikulum adalah segala pengalaman yang dihayati anak (peserta didik) atas pimpinan sekolah termasuk kurikulum. Kurikulum tidak terbatas pada pengalaman anak antara keempat dinding kelas atau pelajaran-pelajaran yang diberikan selama jam sekolah ${ }^{3}$. Dalam kamus Webster bahwa dalam segi pengertian kurikulum ada beberapa arti dari kurikulum antara lain; 4

a. Tempat belomba-lomba, jarak yang harus ditempuh pelari kereta lomba.

b. Pelajaran-pelajaran tertentu yang diberikan sekolah atau perguruan tinngi yang ditujukan untuk mencapai suatu tingkat atau ijazah.

c. Keseluruhan pelajaran yang diberikan dalam suatu lembaga pendidikan.

Menurut Hilda Taba, pada Hakikatnya kurikulum merupakan suatu cara untuk mempersiapkan anak agar berpartisipasi sebagai anggota yang produktif dalam masyasakat. ${ }^{5}$ Dalam kurikulum terdapat komponenkomponen tertentu yaitu pernyataan tentang tujuan dan sasaran, seleksi dan organisasi bahan dan isi pelajaran, bentuk dan kegiatan belajar mengajar, evaluasi hasil belajar. Kurikulum sebagai suatu kegiatan/aktivitas memandang kurikulum merupakan segala aktivitas guru dan peserta didik dalam kegiatan pembelajaran di Sekolah ${ }^{6}$. Kurikulum sebagai suatu hasil memandang kurikulum harus memperhatikan hasil yang dicapai oleh pesesta didik agar sesuai dengan apa yang telah direncanakan ${ }^{7}$. Sukmadinata memandang bahwa kurikulum dapat dilihat dari tiga dimensi, yakni sebagai ilmu, sebagai sebuah sistem, dan sebagai sebuah rencana.

Berbicara masalah kurikulum ketika kita mengkaji masalah ilmu, maka hal yang dikaji dalam ilmu yang berkaitan dengan ilmu adalah

\footnotetext{
${ }^{3}$ Abu Ahmadi, Pengantar kurikulum (Surabaya: PT Bina ilmu Offset, 1984).

${ }^{4}$ Widyastono, 'Pengembangan Kurikulum Sekolah Bertaraf Internasional'.

${ }^{5}$ S. Nasution, Asas-asas Kurikulum (Jakarta: Bumi Aksara, 2003).

${ }^{6}$ Widyastono, 'Pengembangan Kurikulum Sekolah Bertaraf Internasional'.

${ }^{7}$ Ibid.
} 
mengkaji konsep, landasan, teori, asumsi, model, dan hal-hal yang berkaitan dengan prinsip-prinsip dasar dalam kurikulum. Dalam hal komponen dan managemen yang berkaitan dengan kurikulum masuk dalam ranah kajian ilmu yang berkaitan sistem yang ada dalam kurikulum. Dan hal yangterkait dalam rencana yang ada dalam kurikulum berkaitan dengan desain yang ada dalam sebuah kurikulum. Ada desain kurikulum yang berkaitan dengan konsep, tujuan,isi, konsep, proses dan masalah, dan hal yang berkaitan dengan kebutuhan peserta didik dan hal-hal lainnya.

Sedangkan S. Nasution mengemukakan bahwa kurikulum dipandang sebagai suatu rencana yang disusun untuk melancarkan proses belajar mengajar di bawah bimbingan dan tanggung jawab sekolah atau lembaga pendidikan beserta staf pengajar. 8 Menurut Beucham sebagaimana dikutip oleh Nana Syaodih, kurikulum adalah sebagai rencana pengajaran dan sebagai suatu sistem (Sistem Kurikulum) yang merupakan bagian dari sistem persekolahan. ${ }^{9}$

Untuk mengakomodasi perbedaan pandangan tersebut, Hamid Hasan mengemukakan bahwa konsep kurikulum dapat ditinjau dalam empat dimensi, yaitu:

1. Kurikulum sebagai suatu ide; yang dihasilkan melalui teori-teori dan penelitian, khususnya dalam bidang kurikulum dan pendidikan.

2. Kurikulum sebagai suatu rencana tertulis, sebagai perwujudan dari kurikulum sebagai suatu ide; yang didalamnya memuat tentang tujuan, bahan, kegiatan, alat-alat, dan waktu.

3. Kurikulum sebagai suatu kegiatan, yang merupakan pelaksanaan dari kurikulum sebagai suatu rencana tertulis; dalam bentuk praktek pembelajaran.

4. Kurikulum sebagai suatu hasil yang merupakan konsekwensi dari tercapainya tujuan kurikulum sebagai suatu kegiatan, dalam bentuk ketercapaian tujuan kurikulum yakni tercapainya

\footnotetext{
${ }^{8}$ S. Nasution, Kurikulumdan Pengajaran (Jakarta: Bumi Aksara, 2009).

${ }^{9}$ Nana Syaodih Sukmadinata, Pengembangan Ku rikulum, Teori dan Praktek (Bandung:

Rosdakarya, 2002).
}

34 Jurnal Madania: Volume 9 : 1, 2019 (e-ISSN 2620-8210 | p-ISSN 2088-3226) 
perubahan prilaku atau kemampuan tertentu dari para peserta didik.

Abu Dinata dalam optic Terminologis mengartikan bahwa kurikulum sebagai sebuah rancangan program pendidikan yang berisi serangkaian pengalaman yang diberikan kepada peserta didik untuk mencapai suatu tujuanyang ingin dicapai melalui serangkaian belajar ${ }^{10}$. Dari beragam defenisi kurikulum yang memuat pemikiran para ahli bahwa kurikulum itu mengarah pada bebrapa bidang:

1. Sebagai mata pelajaran, Kurikulum ini dikenal sebagai kurikulum klasik,. Dan para ahli tradisional menganggap bahwa kurikulum merupakan mata pelajaran yang akan diajarkan di Sekolah. Sampai saat ini bahwasanya konsep kurikulum klasik ialah sebuah konsep kurikulum yang dominan. Kalau defenisi ini kta renungkan , terlihat bahwa seperangkat mata pelajaran tersebut harus dipelajari siswa di sekolah. Oleh karena itu para ahli cendrung menamkan daftar eperangkat mata pelajaran itu sebagai program belajar daripada kurikulum, walaupun sudah hamper satu abad upaya yang dilakukan oleh para pakar untuk memperoleh pengertian kurikulum yang lebih luas dan mendalam berdasarkan seperangkat mata pelajaran. Konsep kurikulum sebaagi mata pelajaran tetap diakai sebagai basis desain dan pengembangan kurikulum sampai kini.

2. Sebagai Konten, Konten atau materi pelajaran sering sekali dimaknai sebagai kurikulum. Pandangan bahwa kurikulum dikatakan sebagai proses untuk memproses materi ajar dalam buku teks kepada peserta didik yang nanti melalui tes akan ditagih berapa banyak siswa yang menguasai materi itu. Kalau hasil tes sudah menunjukkan bahwasanya seorang siswa sudah mampu untuk menguasai materi dengan baik, maka dia akan dianggap sebagai siswa yang sudah baik sebab dia sudah menguasai apa yang telah diajarkan oleh gurunya dan ini terbukti dengan kemampuan nya mengajarkan materi secara akurat. Implikasi pengertian kurikulum sebagai suatu instrument untuk mentransfer

${ }^{10}$ Farid Hasyim, Kurikulum Pendidkan agama islam (Malang: madani, 2015). 
mata pelajaran kepada siswa menganggap bahwa pengetahuan merupakan suatunkumpulan ilmu yang statis, padahal ilmu dan pengetahuan berkembang esat sepanjang masa, sehingga banyak dan cepat pula pengetahuann dianggap benar akan menjadi using dalam waktu yang tidak lama untuk digantikan oleh pengetahuan baru. Pada awal abad ke 20, banyak pendidik yang memaknai kurikulum tradisioanal yang focus pada transfer konten kurikulum dari guur kepada siswa sedemikian rupa sehingga siswa harus mampu menunjukkan hasil transfer itu di dalam ujian. Konsepsi kurikulum yang tradisional ini serasa amat luas, karena tidak dapat dipastikan pengetahuan dan sikap apa saja yang harus dikuasai siswa dalamkurikulum pembelajaran.

3. Sebagai hasil belajar, selama 40 tahun terahir, kurikulum sudah lebih difokuskan sebagai hasil belajar. Kurikulum tidak hanya dianggap sebagai rancangan saja, lebih difokuskan kepada hasil implementasi rancangan itu di dalam pembelajaran, artinya kurikulum dirancang untuk membuahkan hasil belajar untuk dikuasai siswa. Kurikulum sebagai hassil belajar menunjukkan pergeseran tekanan dari kurikulum yang diartikan sebagai alat ke tujuan. Asumsinya bahwa hasil yang didapatkan merupakan suatu cara yang baik untuk menetapkan tingkat keberhasilan tujuan. Ini tidak identic dengan kurikulum mengarah kepada hasil belajar yang diinginkan, tetapi kurikulum merupakan sebuah realisasi dari implementasi kurikulum yang ada di sekolah bagi perubahan siswa sebagai tujuan. Konsep kurikulum ini megharusan sekolah secara eksplisit dan terperinci terhadap perubahan apa saja yang akan dicapai siswa setelah mereka menyelesaikan sekolah. Di samping itu kurikulum haruslah menspesifikasi proses belajar bagaimana yang akan ditempuh sekolah agar tujuan kurikulum dapat tercapai. Desain kurikulum bukan saja harus memuat materi, tetapi juga kegiatan belajar serta susunan materidan kegiatan belajar yang efektif dalam menghasilkan pengalaman belajar yang relevan dengan tujuan.

Ada bebrapa kekuatan konsep kurikulum sebagai hasil belajar yng berkontribusi pada perkembangan siswa. Defenisi ini lebih fokus pada pencapaian satu perubahan pada diri siswa. 
Bukan pada mata pelajaran atau pada mata ajarnya yang mana pada implikasinya bahwa kurikulum haruslah memuat bukan saja pada materi, tujuan kurikulum dan tujuan intraksional saja, tetapi juga komponen kurikulum lainnya sebagai kegiatan belajar, metode serta susunan materi ajarnya. Komitmen dari sebuah kurikulum berupa kegiatan belajar, metode, dan materi, serta bagaimana dengan evaluasinya. Defenisi kurikulum sebagai hasil belajar haruslah mewaspadai bebrapa hal, yang pertama ialah kurikulum tersembunyi menghasilkan hasil pembelajaran yang tersembunyi negative di samping pembelajaran yang sirencanakan. Kurikulum tersembunyi sebagai dampak dari pendekatan, metode, dan tehnik mengajar, suasana kelas, srategi intraksional tertentu dalam pembelajaran.

Hasil belajar bersama bisa menimbulkan pengalaman yang berbeda pada perkembangan individu siswa. Kedua adalah bahwa kurikulum yang difokiskan pada hasil pembelajaran yang direncanakan beratti mengabaaikan tanggung jawab pada pelaksanaan proses yang sudah bisa dilaksanakan dalam sebuah penyusunan kurikulum, seperti seleksi tema mata ajar yang akan ditetapkan untuk dilaksanakan ada proses pembelajaran. Penentuan konten dan mata ajar tetap dianggap sebagai kegiatan siswa untuk mempelajari materi yangtidak relevan dengan pencapaian suatu tujua yang dapat menjauhkan sekolah dari hasil yang tidak diharapkan.. Ketiga, bahwasanya kurikulum yang direncanakan termasuk sadar atau tidak diajarkan perlulah kiranya untuk mewaspadai karena brekait dengan konten yang kontroversial di masyarakat sehingga para guru tidak mengajarkannya seperti isi tentang pendidikan seks, komunisme, homoseksual, dan lainnya. Kurikulum sebagai hasil belajar memiliki kelemahan besar jika kurang memperhatikan pembelajaran yang tidak direncanakan tetai tanpa disadari guru dipelajari siswa. Padahal hasil kurikulum yang tidak disadari ini bisa merupakan suatu hasil pembelajaran efektif siswa untuk perkembangan yang signifikan.

4. Sebagai reproduksi kultural, artinya sekolah didirikan agar siswa mampu memnghayati pentingnya pengetahaua,moral dan sikap 
dan nilai yang telah dianut oleh orang tua mereka yang telah ditetapkan dalam kehidupan mereka setelah dewasa. Karena kultur dapat menghasilkan cara berfikir dan bersikap dan dapat menjaikan manusia sebagai satu kesatuan sosial. Salah satu hal yang terpenting dalam kultur itu ialah keterampilan hidup yang dapat diwariskan kepada generasi baru sebagai bekal kehidupan bagi anak setelah mereka menjadi orang dewasa. Dengan kultur yang ada generasi muda mampu untuk mewariskan, memelihara dan meneruskan nilai - nilai budaya dan kebudayaan nenek moyng mereka dan tidak akan hilang ditelan masa. Implikasi terhadap fungsi sekolah ialah kurikulum di masyarakat sebagai refleksi kebudayaan masyarakat yang mana sekolah berfungsi sebagai pelaksana reproduksi generasi ilmu pengetahuan dan nilai - nilai yang ada di masa mendatang. Tugas para ahli pendiidkan adalah sebagai pentransformasi butir - butir kebudayaan ke dalam kurikulum dan pembelajaran agar dimiliki dan dapat diaplikasikan oleh generasi muda dalam melaksanakan sosialisasi di masyarakat. Kelemahan kurikulum pada reproduksi kultural ialah konsep kurikulum sebagai sarana untuk mentransfer kebudayaan kepada generasi muda sama saja menjalankan kurikulumsebagai alat kebudataan, dan ini dapat diartikan kurikulum tidak mau untuk melakukan perubahan dan tetap melaksanakan kebudayaan lama yang telah ada dan tetap aja untuk mempertahankan kebudayaan itu. Sekolah yang menggunakan kurikulumini anti perubahan, artinya sekolah tidak melakaukan perbaikan kultural dan reproduksi sosial yang dibutuhkan terkait keinginan masyarakat untuk lebih maju dari masyarakat kini. Orientasi kultural dan rekontruksi sosial bisa mengakibatkan hal yang fatal pada kehidupan sosial masyarakat. Hal ini dapat dicontohkan bahwa yang kaya dan yang berkuasa akan tetap berada di atas dari kelompok masyarakat yang tidak berada, dan para pekerja akan tetap berada di bawah. Ini berarti bahwa kurikulum tidak menyediakan tangga sosial bagi kemajua individu anak dan masyarakat. Padahal pada dasarya pendidikan sangat pro perubahan bagi kemaslahatan umat.

5. Sebagai pengalaman belajar, semenjak akhir tahun 1930 - an, ada yang mengartikan bahwa kurikulum sebagai semua pengalaman 
belajar atau pengalaman pendidikan yang diperoleh siswa sesuai yang direncanakan dan dilaksanakan sekolah. Foshay di tahun 1969 memandan bahwasanya kurikulum bukanlah sebagai kelompok mata pelajaran yang harus diajarkan kepada siswa, tetai sebagai pengalaman yang diperoleh anak - anak di bawah arahan guru. Saylor dan Alexander mengartikan kurikulum itu lebih puas dari pengalaman yang diperoleh siswa, tetapi mereka memandang bahwa kurikulum sebagai upaya bersama sekolah untuk mencapai tujuan yang diinginkan, baik melalui pembelajaran di kelas dan lingkungan sekolah, maupun di luar sekolah. Mark dan Jamisson di tahun 1989 mendefenisikan kurikulum sebagai seperangkat pengalaman belajar yang dimiliki siswa dalam suatu pembelajaran. Defenisi ini lebih luas dari defenisi kurikulum sebelumnya yang hanya membatasi kurikulum dari rencana saja, atau sekedar mengajarkan mata pelajaran atau materi ajarnya. Dalam kurikulum sebagai pengalaman yang mencakup pengertian bahwa kurikulum bukan hanya rancangan tertulis untuk melaksanakan proses pembelajaran kepada siswa, tetapi termasuk implementasi dari rancangan itu yang dilaksanakan di dalam kelas, di sekolah, dan di lingkungan masyarakat. Defenisi kurikulum yang terkait dengan keseluruhandari pengalaman belajar semakin popular. Sebagian ahli pendidikan berpendapat bahwa kurikulum bukan hanya mengacu kepada seperangkat mata pelajaran atau mata kuliah saja tetapi jauh lebih sempurna, yang mana kurikulum dapat memberikan pengalaman yang membangun bagi diri siswa melalui semua kegiatan dan lingkungan belajar yang direncanakan dan diprakarsai sekolah.. Hal ini menunjukkan bahwa dinamika dari kurikulum ialah dari sebagai rancangan tertulis berkembang menjadi hasil implementasi rancangan kurikulum berupa pengalaman belajar atau pengalaman pendidikan. Pengalaman dan kompetensi yang dimiliki siswa dapat berfungsi secara optimal di masyarakat. Seseorang yang memiliki pengalaman terhadap sesuatu, maka dapat mengembangkan menjadi sebuah kompetensi melalui kompetensi di dalam melaksanakan proses pembelajaran. Pengalaman pendidikan dikatakan sebagai embrio dari sebuah kompetensi sebagai atribut terhadap apa yang dilakukan oleh siswa, dan bukan sekedar pengetahuan yang 
dimiliki oleh siswa. Karena sangat luas cakupan kurikulum yang terkait dengan pengalaman, maka banyak para ahli yang menolak dan menerima konsep ini. Maksudya menerima konsep ini dikatakan bahwasanya kurikulum adalah semua cara yang ditempuh oleh siswa agar sama - sama memperoleh kesempatan belajar untuk memiliki pengalaman yang diinginkan. Beberapa pakar yang menolak konsep ini ialah Taba tahun 1962, Johnson di tahun 1967, dan Inlow di tahun 1973, dikarenakan mereka menganggap bahwa kurikulum terlalu luas cakupannya sehingga tidak jelas mana pengalaman yang diperoleh siswa mellaui kurikulum di sekolah atau urikulum yang dieroleh di luar sekolah. Doll di tahun 1970 mencatat bahwa terdapat pergesran konsep kurikulum. Dari konten urikulum atau seperangkat pembelajaran menjadi semua pengalam belajar yang direncanakan sekolah. Menurut dimensi ini bahwasanya guru berperan sebagai fasilitator perkembangan individual siswa dari pada se

6. bagai pengalaman siswa. Dengan demikian bahwasanya kurikulum dirancang sebagai fasilitator perkembangan individual siswa dari pada sebagai pengajar siswa, karenanya kurikulum dirancang untuk memperoleh pengalam sisiwa mellaui proses pembelajaran interakti antara siswa, guru, materi, serta lingkungan belajar. Walaupun kurikulum sebagai pengalaman dikritik secara luas, namun banyak dari pakar pendiidkan yang enerima konsep ini. Kurikulum dikatakan bukan hanya sebagai dokumen mati yang memuat rencana dari sesuatu yang ideal untuk membelajarkan dari siswa, namun sebagai sebuah dokumen yang ideal itu harusaah diimplementasikan oleh guru di dalam kelas untuk membekali siswa dengan berbagai pengalaman yang bermakna, bukan hanya sekedar menghasilkan pengalaman yang harus mereka ketahui untuk dihapal. Bahwa pengalaman belajar lebih menggambarkan keadaan yang lebih akurat dari sebuah kurikulum. Sekolah diidrikan untuk mendiidk siswa agar lebih berkembang secara optimal. Lantas pengalaman yang didapat oleh siswa akan berkembang secara optimal jika siswa mmeperoleh pengalaman yang banyak di sekolah. Ini berarti bahwa kurikulum sebagai cetak biru pendidikan yang ada di sekolah harus bermuara pada penguasaan aplikatif dan integratif 
pengetahuan, keterampilan, dan nilai oleh individu siswa sampai berakumulasi menjadi pengalaman dan kompetensinya. Adapun konsep kurikulum sebagai pengalaman terkait dengan dua hal, yaitu bahwasanya kurikulum itu tidak akan bermanfaat jika kurikulum tidak berpengaruh pada peningkatan hapalan atau dalam artian kurikulum hanya difokuskan saja pada menghasilkan hapalan dari siswa saja, dan yang kedua ialah pengalaman itu perlunya sebuah implementasi kurikulum yang menghasilkan pengalaman, asalkan pengalaman itu berkontribusi pada pencapaian tujuan pendidikan.

7. Sebagai sistem produksi, bahwasanya kurikulum adalah seperangkat tugas yang dapat menghasilkan pendidkan. Biasanya tujuan akhir itu dalam bentuk tingkah laku seperti mempelajari keahlian, tugas, atau mempelajari suatu tingkah laku dengan lebih baik. Konsep kurikulum ini merupakan aplikasi managemen dan industri pada pendidikan seperti yang terlihat pada analisis tugas. Pendekatan ini dikatakan sebagai pendekatan industry, seperti yang ada di pabrik maka dilakukan dahulu pendekatan berupa tugas atau tingkah laku yang akan dicapai, teknologi intraksional termasuk analisis sistem dan akuntabilitas. Menurut Popham di tahun 1969, kurikulum hanya berupa sebagai sebuah pertimbangan yang merupakan hasil akhir pendiidkan berupa tujuan intraksional yang harus dicapai oleh siswa. Tujuan intraksional itu haruslah dinyatakan secara jelas dan dapat dirumuskan dalam betuk tingkah laku yang diinginkan dan hasilnya dalam bentuk operasional dengan bisa dilihat dan diukur. Popham adalah seorang ahli pendidikan yang mmebedakan antara kurikulum dan pengajaran, yang mmebedakan antara ke duanya adalah tujuan dan alat untuk mencapai tujuan itu. Namun antara kurikulum dan pengajaran itu sama-sama bertujuan untuk mengimplementasikan produk akhir atau dikatakan sebagai terminal, bahwa tingkah laku siswa dapat terukurdan terlihat serta relevan dengan tujuan pendidikan. Popham juga mengatakan bahwa sistem pendiidkan juga perlu diidentifikasi dengan tujuan yang ingin dicapai secara persis dan mengumpulkan dalam bank tujuan tingkah laku yang mudah diakses guru sehingga guru tidak mudah untuk menghabiskan waktu melakukan identifikasi dari 
sebuah tujuan karena tujuan -tujuan yang ingin di tulis sehingga dapat diimplementasikan sudah ada dalam bank tingkah laku yang sudah diakses. Guru bukanlah sebagai seorang mekanik. Guru hanya memiliki tugas pokok sebagai pelaksana pendiidkan dan menjaga kurikulum beserta semua komponen proses teknologinya agar menghasilkan produktifitas yang memadai melalui kualitas control yang baik dari seorang guru. Pandangan ini bertumpu pada teori Skinner yang ada pada tahun 1968, yang dikenal dengan teori Operant conditioning, yang menyatakan bahwa tugas dari seorang guru bersifat mekanik, yaitu mengusahakan adanya penguatan berupa rangsangan agar siswa pada tujuan akhirnya dapat bertingkah laku seperti yang diinginkan oleh kurikulum. Kritik dari konsep ini ialah kecendrungan untuk memandang pendidikan sebagai suatu mesin mekanis bagi pencapaian kognitif terendah, seperti mengingat dari sebuah informasi yang dihasilkan dan didapatkan sehingga sebuah informasi itu dapat untuk dihapalkan. Kurikulum menurut konsep tujuan tingkah laku, identic dengan komponen proses produksi teknologi. Menurut konsep ini bahwasanya peningkatan proses teknologi perlu kiranya untuk ditingkatkan dalam bentuk produktivitas guru mengajar. Zais memandang bahwa konsep teknologi dapat kiranya mengatasi masalah utama di dalam dunia pendidikan . Pendekatan teknologi juga memandang bahwasanaya kurikulum adalah sebagai mesin kurikulum yang dapat djalankan dengan cara menghidupkan stop kontak. Sebagaimana pendapat Bush dan Allen di tahun 1964 memberikan perumpamaan bahwasanya keseluruhan dari sebuah kurikulum dianggap sebagai arena yang akan digarap. Yang mana dimensi horizontalnya ialah jumlah pelajar yang akan diajar, dan dimensi vertikalnya terkait dengan lamanya proses penggarapan arena itu dan orientasi teknologi juga dapat menghasilkan kurikulum sebagai kotak segi empat dengan umlah siswa terkait dengan variable jumlah murid yang diproses pada waktu yang tersedia untuk diproses. Adapun implikasi dari orientasi kurikulum bersifat teknologi antara lain belajar bersifat linier dan mekanistik, sedangkan siswa dianggap sebagai benda mekanik yang dapat dikondisikan untuk menghasilkan pembelajaran secara otomatik. Di samping itu bahwasanya orientasi defenisi kurikulum berasumsi bahwasanya keseluruhan proses pembelajaran bersifat aditif, yaitu 
keseluruhan jumlah unit yang dipelajari oleh siswa merupakan gabungan dari semua kepingan unit yang membentuknya. Selanjutnya bahwa tingkat belajar yang lebih tinggi, seperti apresiasi, pengetahuan tentang pengetahuan diri sendiri atau disebut metakognitif, serta nilai -nilai yang didapat amatlah sulit untuk dapat diperoleh mellaui latihan seperti yang dinyatakan dalam konsep kurikulum sistem produksi.

8. Sebagai bidang studi, kurikulum adalah sebagai bidang studi atau mata pelajaran yang memiliki fondasi dan ruang lingkup sendiri seperti bidang studi lain yang memiliki riset, teori dan prinsip yang ada. Kurikulum sebagai bidang studi muncul dalam buku Bobbit sebagai pakar pendidikan di tahun 1918 dalam bukunya The Curriculum yang memuat prinsip dari sebuah perencanaan kurikulum yang berintikan mata pelajaran yang harus diajarkan kepada siswa. Lantas Bobbit juga menggariskan bahwasanya prinsip pengembangan kurikulum, yaitu agar kurikulum menetapkan pengetahuan penting dalam tiap mata pelajaran dan mengembangkan kegiatan yang tepat untuk mencapai tujuan kurikulum terutama di sekolah dasar. Tahun 1990 diangga sebagai tahun lahirnya kurikulum sebagai bidang studi. Di masaitu diterbitkan bebrapa buku yang berkaitan dengan kurikulum dan njuga bermunculan buku dan proyek yang berisi tentang kajian kurikulum dan penyempurnaannya yang pada masaitu merupakan hal yang dianggap baru. Perkembangan selanjutnya ialah tumbuh di laboratorium di tahun 1926 yang mana mengkaji kurikulum sebagai suatu inovasi. Akhirnya di tahun 1930 - an perkembangan kurikulum sebagai suatu bidang studi mencapai puncaknya. Hal ini dapat dilihat dengan bermunculannya Departemen Pendidikan Negara Amerika Serikat yang mana mereka tertarik pada revisi dan perbaikan kurikulum termasuk implementasinya di dalam kelas. Sekolah tinggi di bebrapa jurusan pada universitas mendirikan jurusan kurikulum pendidikan departemen kurikulum dan pembelajaran pada Teacher Colege, Colombia University pada tahun 1937, dianggap sebagai suatu kelahiran pada bidang studi bernama kurikulum. 
Para ahli berbeda pendapat tentang makna kurikulum dan pemebalajaran, Johnson di tahun 1968 memandang kurikulum sebagai penduaan belajar, maka itu disebut pengajaran bukan kurikulum. Dia memandang bahwasanya kurikulum ialah seperangkat hasil belajar yang terstruktur yang akan dicapai oleh sekolah. Pengajaran bukanlah kurikulum. Seorang ahli pendidikan yang ternama Beauchamp di tahun 1981 mengganggap bahwa kurikulum dan pembelajaran sebagai dua hal yang berbeda. Ke dua pakar ini mengkaji bahwa kurikulum merupakan "apa nya" pendidikan sementara pengajaran mengenai " bagaimananya " pendidikan, dengan perkataan lain bahwasanya pengajaran menyangkut hal - hal yang lebih tekhnis yaitu terkait hal - hal yang menyangkut proses penyampaian konten atau materi pelajaran. Seorang pakar ternama bernama Oliva di tahun 1982 memrinci bahwa kurikulum bersifat program, rencana, konten, dan pengalaman belajar, sedangkan pengajaran lebih bernuansa pada metodologi, strategi, tekhnik pengajaran, implementasi dan oresentasi dari sebuah program, rencana, dan konten kurikulum tersebut. Di tahun 1965 James Macdonald memandang bahwa kurikulum sebagai suatu rencana implementasi pengajaran di kelas, karena kurikulum timbul lebih dahulu dari pengajaran.

Parkay menegaskan bahwa kurikulum dan pengajaran berkaitan sangat erat, ke dua nya saling berkaitan satu sama lain denganfungsi yang berbeda. Kurikulum sebagai "apanya "dan pengajaran sebagai " bagaimananya ", ke duanya diibaratkan sebagi dua sisi mata uang yang sama, karenanya dikatakan antara kurikulum dan pengajaran merupakan dua bagian yang integral dari pendidikn dan pengajaran yang saling berkaitan dan mmepengaruhi. Misalnya ketika ditetapkan suatu materi dari konten kurikulum untuk diajarkan bagi siswa tertentu dalam proses pengajaran, berarti juga ditetapkan metode tertentu, agar kontten atau materi itu menjadi pengetahuan, keterampilan atau nilai yang bermakna bagi siswa.

Implikasi perbedaan pengertian kurikulum dan pengajaran seperti yang dikemukakan oleh Johnson, Macdonald, dan Oliva tersebut sangat signifikan. Zais mengatakan bahwa dengan 
membatasi pengetian kurikulum pada seperangkat hasil belajar terstruktur saja, berarti pelaksanaan rancangan tradisional seperti seleksi konten kurikulum atau materi ajar dan penetapan kegiatan belajar, bukan termasuk perencanaan kurikulum. Menurut pengertian ini bahwa proses dalam kelas merupakan implementasi dari perencanaan pengajaran, bukanlah implementasi dari kurikulum yang hanya berupa pencapaian hasil belajar.

Zais juga menggugat bahwa defenisi yang diungkapkan oleh Johnson bahwasanya akan menimbulkan kesulitan dalamkonsep teoritis dan praktis. Zais yakin bahwa usaha yang dilakukan oleh seorang pakar ternama yang bernama Johnson memisahkan antara hasil dan proses serta cara yang ditempuh dan hasil yang dicapai, adalah suatu yang mustahil. Pendapat dari Johnson ini juga tidak sesuai dengan suasana yang dihadapi di sekolah disetiap saatnya. Zais juga berpendapat bahwasanya jika stiap pakar kurikulum hanya membatasi perhatiannya pada formulasi seperangkat hasil belajar yang ingin dicapai saja, maka mereka menghindar pada tanggung jawab dan hal -hal yang sangat esensial dan sudah lumrah yang dilakukan oleh perancang dan pengembang kurikulum, yaitu seleksi konten dan materi ajar serta perencanaan kegiatan belajar yang relevan dengan pencapaian tujuan.

\section{Pembaharuan Kurikulum Era Orde Baru di Madrasah Aliyah}

Setelah Suharto mengukuhkan kekuasaan dan berhasil melenserkan Soekarno pada tanun 1968, maka masa ini disebut masa orde baru. Adapun periode kurikulum di masa orde baru adalah:

1. Kurikulum MA sebelum tahun 1973

Kurikulum di masa ini belumlah muncul secara nasional, masih ditentukan oleh lembaga pendidikan masing-masing. Antara madrasah yang satu dengan yang lainnya memiliki rancangan yang berbeda terkait dengan rencana pengajaran. Karakteristik kurikulum tahun 1973 pembelajarannya masih berpusat pada guru sebagai satu-satunya sumber belajar, evlulsi pembelajaran dalam 
kurikulum masih terfokus pada isi atau materi, dan dikatakan bahwasanya kurikulum MA tahun 1973 didominasi oleh muatan umum $^{11}$

2. Kurikulum MA tahun 1975

Ciri-cirinya adalah bahwasanya kurikulum ini lebih menekankan pada tujuan atau hasil, dan proses tidak begitu diperhatikan. Guru menjadi sentral dan satu-satunya sumber belajar dalam kurikulum menggunakan tes berupa nilai formatif dan sumatif ${ }^{12}$.

3. Kurikulum MA 1984

Dengan lahirnya kurikulum 1984 sebagai penyempurnaan kurikulum 1975 maka pada saat itu lahirlah surat keutusan bersama antara mentri agam dengan mentri P dan $\mathrm{K}$ no 02 tentang pengakuan pembentukan kurikulum sekolah umum yang isinya membicarakan lulusan sekolah madrasah agama dapat melanjutkan pendidikan kesekolah umum yang lebih tinggi. Adapun analisis isi dari SKB dua mentri terkait dengan;

a. Bahwasanya kurikulum madrasah terdiri dari program inti dan program khusus.

b. Program inti bertujuan untuk memenuhi tujuan pendidikan sekolah menengah umum.

c. Program khusus yang bertujuan untuk memberikan bekal kepada mahasiswa yang akan melanjutkan ke Perguruan tinggi serta beberapa hal yang terkait dengan pendidikan yang ada di madrasah yang menerapkan bahwasanya ciri khas madrasah harus memenuhi kajian kelslaman.

Masa UU system pendidikan nasional no 2 tahun 1989 dan kurikulum MA 1994. Kurikulum MA tahun 1989 disusun untuk mewujudkan tujuan pendidikan nasional dan mepertahankan tahap

\footnotetext{
${ }^{11}$ Abdul Rahman Shaleh, Madrasah da n Pendidikan Anak Bangsa (Jakarta: Raja Grafindo Persada, 2004).

${ }^{12}$ dkk Mawardi Suetejo, Kapita Salekta PAl (Jakarta: Dirjen Bimbingan Islam dengan Universitas Terbuka, 1992).

46 Jurnal Madania: Volume 9 : 1, 2019 (e-ISSN 2620-8210 | p-ISSN 2088-3226)
} 
perkembangan siswa yang disesuaikan keberadaan lingkungan. Kurikulum 1994 memiliki ciri khas tersendiri, yang meliputi kurikulum 1994, yang dirancang dengan cermat melihat pada sisi kelemahan yang terdapat pada kurikulum MA pada tahun 1989. Pembelajaran lebih diutamakan pada proses, guru pada kurikulum 1994 diberi kewewenangan untuk berimprovisasi dngan kurikulum yang telah disusun, Guru diberi leluasa untuk mengatur alokasi waktu dalam mengajarkan setiap pokok bahasan dan sub pokok bahasan yang disesuaikan dengan sub pokok bahasan yang disesuaikan dengan kedudukan, dan guru juga di beri wewenang dalam menentukan metode, penilaian, dan sarana pembelajaran sesuai dengan kebutuhan sehingga siswa aktif dalam setiap pembelajaran baik secara fisik dan mental.

Dari berbagai kebutuhan kurikulum dan juga fase kurikulum yang sudah penulis jelaskan, bahwasanya kurikulum di masa orde baru mempunyai tujuan manusia seutuhnya.

1. Malik Fajar menetapkan ada tiga tuntutan minimal dalam meningkatkan kualitas Madrasah, yaitu

a. Bagaimana menjadikan Madrasah untuk membina ruh dan praktek hidup keislaman.

b. Bagaimana memperkokoh keadaan Madrasah sehingga sederjat dengan system sekolah.

c. Bagaimana Madrasah mampu untuk merespon tuntutan masa depan guur yang terinspirasi perkembangan iptek dan globalisasi ${ }^{13}$.

Mampukah kurikulum MA mempertahankan ciri khas keislaman di masa orde baru ? Untuk menjawab hal itu dalam buku Madrasah dan Pendidikan anak bangsa yang dibuat oleh Abdul Rahman Shaleh menjawab bahwasanya " Mulai dari kurikulum yang $100 \%$ agama, $90 \%$ agama dan $10 \%$ umum, $80 \%$ agama dan $20 \%$ umum, $70 \%$ agama dan $30 \%$ umum, $60 \%$ agama dan $40 \%$ umum, $50 \%$ agama dan $50 \%$ umum, $30 \%$ agama dan $70 \%$ umum, dan seterusnya ${ }^{14}$

Teori ini membuktikan bahwa karakteristik dari kurikulum Madrasah Aliyah tidak boleh hilang, walaupun kurikulum terus mengalami

\footnotetext{
${ }^{13}$ Muhaimin, Perkembangan kurikulum dalam pendidikan islam di sekolah, Madrasah, dan Perguruan Tinggi.

${ }^{14}$ Shaleh, Madrasah da n Pendidikan Anak Bangsa.
} 
pembaharuan pada vasenya. Menurut Stenbrink madrasah memiliki isi kurikulum, metode, dan cara mengajar sendiri yang berbeda dengan Sekolah. Meskipun mengajarkan ilmu pengetahuan umum, sebagaimana yang diajarkan di Sekolah, madrasah juga sangat menonjolkan nilai religious keislaman masyarakat. ${ }^{15}$

Kurikulum MA yang mulai secara nasional setelah tahun 1973, di mana didominasi oleh pelajaran umum di MA sudah mulai kelihatan, mata pelajaran agamanya sudah mulai berkurang dan kurikulumnya sudah seragam secara sentralisasi. Pembaharuan terus saja bergulir sampai pada tahun 1975, yang dikenal dengan kurikulum SKB. Begitu juga dengan kurikulum 1984. Kemudian pada tingkat pembelajaran agama semakin berkurang hingga akhirnya muncul UUSPN NO 2 tahun 1989, yang mengakui bahwa madrasah sebagai suatu system Nasional yang berimplikasi pada pengurangan mata pelajaran agama yang sangat drastic. Dengan terus mengembangkan pada arah implementasi kurikulum di masa orde baru, bahwasanya untuk countent pendidikan agama islam tetap dilebihkan dari SMA sebagai eksistensi untuk mempertahankan isi pada kurikulum Madrasah Aliyah.

Analisis Pembaharuan kurikulum MA masa orde baru serta tingkatan kebijakan kurikulumnya

Masa orde baru, pada pembaharuan kurikulum MA tahun 1973, maka kurikulum yang ada di MA sudah di bagi perjurusan. Yakni jurusan IPA,IPS, dan bahasa, yang mana pada saat itu muatan yang ada pada kurikulum MA Pada saat ini kurikulum MA sudah dikatakan berdiri secara nasional yang mana muatan agama $29.2 \%$ dan muatan umum $70.8 \%$.

Pada pembaharuan kurikulum di tahun 1976 . Ini terjadi pada tahun 1973 ke kurikulum tahun 1976 yang sudah dikatakan lebih matang yang mengarahkan pada penekanan isi kurikulum $30 \%$ pelajaran agama dan $70 \%$ pelajaran umum, Jurusannya sudah semakin bertambah yakni IPa, IPS, Bahasa dan Syariah Agama dengan muatan kurikulum yang berbeda-beda. namun tujuan kurikulum MA tahun1976 tidak disebutkan siap berkompetensi dalam dunia pekerjaan. Adapun kebijakan yang ada di tahun 1976 terkait dengan pembaharuan kurikulum MA, terkait dengan kesepakatan tiga menteri, yang mengakui bahwasanya lulusan MA, dapat melanjutkan ke Sekolah Umum yang lebih tinggi seperti Universitas umum.

15 Stenbrink, Pesantren, Madrasah dan Sekolah, Pendidikan Islam dalam kurun modern. 48 Jurnal Madania: Volume 9 : 1, 2019 (e-ISSN 2620-8210|p-ISSN 2088-3226) 
Pembaharuan kurikulum di tahun 1984, maka untuk program jurusan yang ada di MA semakin banyak, yakni jurusan fisika, biologi, sosial budaya, yang terkait pada kebijakan yang telah dibuat oleh penetapan SKB 3 Menteri dan memunculkan SKB 2 Menteri yang mengarah pada kebijakan kurikulum MA yang bersifat centralisasi, yakni satu sistem pendidikan nasional.

Adapun kurikulum MA di tahun 1994 dengan program IPA, IPS, Bahasa dengan muatan agama $15.6 \%$ agama dan $84.4 \%$ umum. Adapun program agama di MA umum tidak ada lagi seperti kurikulum tahun 1984, program agama tahun 1994 berdiri sendiri menjadi madrasah Aliyah keagamaan, ini terkait dengan kebijakan UUSPN no 2 tahun 1989, mengakui bahwa MA sebagai suatu sistem dari pendidikan nasional dengan persyaratan muatan umum disamakan dengan SMU.

\section{Kesimpulan}

Kurikulum Ma di masa orde baru sudah mulai seragam atau bersifat centralisasi sejak muncul kurikulum di tahun 1975, atau yang dikenal dengan kurikulum SKB 3 Menteri. Kurikulum ini menjadi seragam dan merupakan sebuah persyaratan yang urgen supaya MA di samakan statusnya dengan Sekolah Umum dan diakui secara Nasional, ini terkait dengan UU No 4 tahun 1950 dan UUSPN NO 2 tahun 1989. Kebijakan pendidikan yang terkait dengan kurikulum di MA mengiring kepada sistem secara nasional, bahwasanya kurikulum di MA sama dengan kurikulum di MA, tetapi tetap mempertahankan ciri khas keislamannya, atau dikenal dengan Sekolah Umum berciri khas Agama Islam. Di masa orde baru ini, kurikulum agama sudah bersifat nasional. Dengan mengakui bahwa Madrasah Aliyah sebagai sub sistem dari pendidikan nasional. Jurusan agama di MA masa orde baru menjelma menjadi Madrasah Aliyah program khusus atau dikenal dengan MAPK.

\section{DAFTAR PUSTAKA}

Abu Ahmadi, Pengantar kurikulum, Surabaya: PT Bina ilmu Offset, 1984.

Farid Hasyim, Kurikulum Pendidkan agama islam, Malang: madani, 2015.

Mawardi Suetejo, dkk, Kapita Salekta PAl, Jakarta: Dirjen Bimbingan 
Islam dengan Universitas Terbuka, 1992.

Muhaimin, Perkembangan kurikulum dalam pendidikan islam di sekolah, Madrasah, dan Perguruan Tinggi.

Nana Syaodih Sukmadinata, Pengembangan Ku rikulum, Teori dan Praktek, Bandung: Rosdakarya, 2002.

Peran Madrasah untuk mencerdaskan kehidupan bangsa. Yang dapat dilihat dari UU pendidikan pada tahun 1950. Dengan bergesernya peran pembaharuan kurikulum dari tahun 1950 ke tahun 2019, maka tidak akan dapat teralpakan bagi peran Madrasah yang ikut dalam $m$.

S. Nasution, Asas-asas Kurikulum, Jakarta: Bumi Aksara, 2003.

----, Kurikulumdan Pengajaran, Jakarta: Bumi Aksara, 2009.

Shaleh, Abdul Rahman, Madrasah da $n$ Pendidikan Anak Bangsa, Jakarta: Raja Grafindo Persada, 2004.

Stenbrink, Pesantren, Madrasah dan Sekolah, Pendidikan Islam dalam kurun modern.

Widyastono, Herry, 'Pengembangan Kurikulum Sekolah Bertaraf Internasional', Jurnal Pendidikan dan Kebudayaan, vol. 16, no. 3, 2010, p. 5 [https://doi.org/10.24832/jpnk.v16i3.460]. 